\title{
Flipped Classroom Model - A Response to the Emerging Trends in the Teaching Learning Landscape
}

\author{
Sudha Srinivasan, Harish Kumar
}

\begin{abstract}
Flipped Classroom Model has emerged over the last two decades and its popularity is growing rapidly in the recent years. This study reviews and analyses the research on Flipped Classroom Model in higher education from a variety of aspects. The main aim of this study is to identify the factors that influence the popularity of Flipped Classroom Model and making it a worthwhile activity to implement. The study also examines the new trends and rapid transformation in the digital and education landscape and the associated changes in the current education system. A six-step process suggested by Cooper \& Hedges (2011) is used to identify and synthesis the data required for this study. Findings from the study show positive influence of Flipped Classroom Model in higher education on different parameters including students' academic achievement and their level of engagement. Further, this paper discusses the opportunities and challenges in designing and implementing Flipped Classroom Model deeply associated with our traditional higher education system.
\end{abstract}

Keywords: flipped classroom model, higher education, research synthesis, student engagement.

\section{INTRODUCTION}

While the world aligns with the big data management and digitalization, data dumping prevailed in the classrooms as the instructors flood the students with extensive information to cover the scholastic curriculum. Equipping students seemingly for the future world was an unreasonable matter with the role of educators.

Technology advancements and innovations dominate all sectors of society in the modern world. While different domains were quick to adapt to the changes, education sector remained comparatively unchanged till the massive digitalization. A look into many classrooms has literally proven the incapability of the sector in adopting the rapid changes in the recent past decades. Though the classrooms are equipped with new technology like smart boards, the method of teaching and learning remains more or less unchanged when compared with the traditional ways.

The theory and practice of learning is referred to as 'pedagogy'. The term refers to various elements in the teaching-learning process like instructors, students, learning environment and learning tasks. The nature of relationship between teachers and students as well as the teaching and

Revised Manuscript Received on November 11, 2019.

* Correspondence Author

Ms Sudha Srinivasan, Research Scholar, Amity Institute of Education, Amity University, Uttar Pradesh

Dr. Harish Kumar, Head, Amity Institute of Behavioural \& Allied Sciences (AIBAS), Amity University, Uttar Pradesh learning approaches utilized in the instructional design is confined in the term 'pedagogy'. Conventional methods of teaching are replaced in the modern world of teaching with different perspectives on learning. Current teaching methods combine the traditional and modern perspectives of learning to effectively use the range of possibilities in pedagogy.

In the domain of Teaching and Learning, the Flipped Classroom Model (FCM) is a new instructional strategy, which uses digital learning as an effective tool. FCM is the reverse of Traditional Learning Method (TLM) where delivery of content often happens online or at the exterior environment of usual classrooms. In FCM students can use online media as a learning medium as well as a platform for collaborative discussions.

\section{NEED AND SIGNIFICANCE OF THE STUDY}

Current research is focused on the impact of FCM, a new pedagogical approach on the student community. In TLM, sharing of knowledge is not effectively enunciated, as it is a one-side approach. Instructors play a prominent role in teaching and learning as they share their knowledge with the students. Student participation or sharing of their views is comparatively less or nil in this kind of approach. The new approach of FCM enables and equips the student community to gather knowledge from the online platforms instead of traditional face-to-face approach. Present research analyses the impact of FCM on the learners from the previous studies conducted by the researchers. Cognitive and constructivist theories are integrated to evaluate the results of the new pedagogical approach.

The present era is witnessing swift changes in information technology domain and the education sector experiences specific countenance or serious compulsion to replace the TLM with modern learning techniques. The new learning techniques should leverage the power of technology to the fullest extent and should inculcate latest skills such as Critical thinking, Collaborative learning, Communication and Creativity. Many kinds of research on the effectiveness of FCM have proved it to be more suitable in the modern scenario. Similar studies throw light on the challenges involved in transitioning to a new model, identifies factors that can influence the teaching-learning process when FCM is used.

The present research study focuses on reviewing the existing studies done so far in the adoption of the FCM in the education sector and on identifying the need for further study. A review is carried out on related research studies to

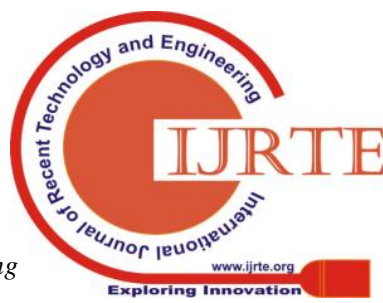


see the trends, observations and findings from the researchers across the globe. This study is delimited to the university level courses and classrooms where FCM have been experimented.

\section{OBJECTIVES:}

The study has been able to achieve the following objectives:

1) To analyze various perspectives and views on the concept of FCM

2) To explain the concept of the FCM as a worthwhile activity to provide an engaging learning experience for the learners

3) To identify and understand the key components of the FCM and their relevance

4) To articulate the changing role of teachers and students in the context of the FCM

\section{RESEARCH QUESTIONS:}

The following research questions formed the basis of the present study:

1) What are the various perspectives and views on the concept of flipped classroom model?

2) What are the pedagogical factors that make FCM a worthwhile activity to provide an engaging learning experience for the learners?

3) What are the key components of FCM ?

4) What are the challenges faced by the different stakeholders in adopting FCM?

5) What is the impact of FCM on student's learning?

\section{RESEARCH METHODOLOGY:}

The process of identifying and synthesizing the available research articles was based on the six-step process suggested by Cooper \& Hedges (2011)

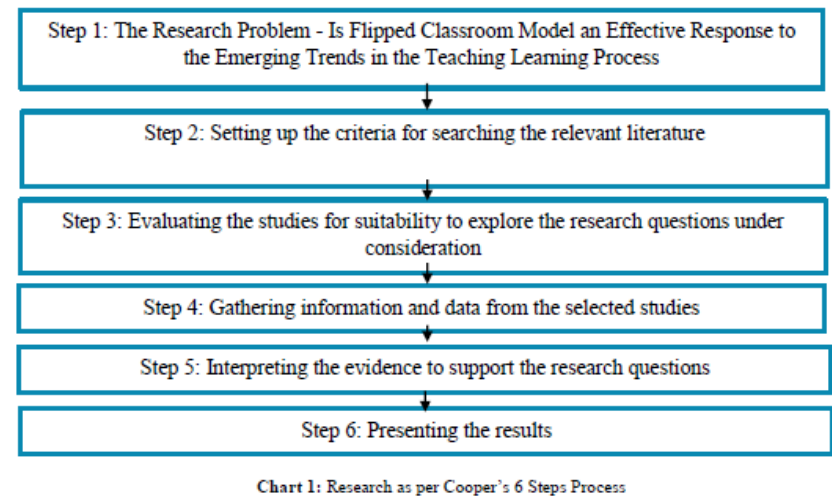

Current research problem explained with Cooper's 6 step process below:

\section{Step 1. The Research Problem:}

Is Flipped Classroom Learning an Effective Response to the Emerging Trends in the Teaching Learning Process

Traditional Learning Model (TLM) has the inability to make students actively participate in the learning process. The lectures delivered in the classrooms fail to hold the attention of the students for the required period. The need for a more active and effective method that will make students actively involved in the learning process through various methods and techniques arises because of the weakness of the TLM. The utilisation of modern techniques in scholastic curriculum will equip students with effective knowledge sharing and enhanced engagement. Students can be more pro-active with the support of the new techniques in their academic activities. Active learning has got much weightage as the active elements like deep learning, concentration etc. have found to have a positive or active effect on students, while procrastination in upper-level learning can have a negative effect on students.

Flipped Learning is a method of learning that has an active effect on students. The word flipped is related to the word inversed. In flipped learning the traditional method of education is inversed with the latest tools available for learning, making the students actively participate in the learning process. Online classes and video-based studies can be used for teaching the students in flipped method. As a result, the education system benefits with more time and space for teaching rather planning for making students engaged and concentrated. In a flipped classroom model students are taught via video-based or video recorded teaching modules, or through problem-solving technique, which will engage them more. Homework on problem-solving skills can be done as a group activity through Internet medium where students will involve in smaller or larger groups in order to solve the problem. A community of peer learners can be created where students can join with a group during their study process, making it more engaging and fun to learn, as it's their peer whom they learning with. The flipped model has some features like:

- Flexible timing

- Better utilization of outside classroom time

- An effective way of class homework's completion

- Productive in-class, out of class tasks

- Active learning, peer circle learning and deep learning

- Efficient learning activities prior and post the class

- Usage of modern technology in education

\section{Step 2. Literature Review}

There is a sizeable and increasing literature of studies investigating FCM, on different factors comparing it with the Traditional Lecturing Method. The popularity of FCM does not match the magnitude of primary research studies. The criteria of inclusion in literature review:

1. Papers that included the words "Flipped Learning", "Flipped Classroom", "Flipping", "Reverse Teaching" in the title

2. Papers published between 2015 and 2018 in English Language

3. Papers with variables associated with learning

4. Setting is based on the Course of study, Methodology adopted in research, Duration of the study and Sample size

5. Findings and Conclusions based on the research data analysis and which gives further scope for FCM model in learning

\section{Step 3: Evaluating the Suitability of the studies}

Articles and review papers on 'flipped learning' were examined and evaluated to establish the desired outcome of the research. Aspects under consideration while collecting data

1. Reliability of data

2. Suitability of data

3. Accuracy 
Kevin r. Clark, et al (2015) studied The Effects of the Flipped Model of Instruction on Student Engagement and Performance in the Secondary Mathematics Classroom and discussed that FCM gave the possibilities of an active Mathematics classroom instead of a passive one. The students performance was analyzed based on pre and post-survey record and were monitored on daily basis. By making classroom activities and the home work more engaging, active learning happened in the class. The students demonstrated positive influence and response to flipped learning.

Stacy M.P. Schmidt et al., (2016) in 'The Flipped Classroom: A Twist on Teaching' discussed that the flipped classroom was found as one the effective way of teaching students in the modern education system. The study deals with the methods of flipped classroom since it has various ways of implementing it. The pros and cons of flipped classroom are also discussed in this paper.

Arina Evseeva et al., (2015) analyzed the Use of Flipped Classroom Technology in Language Learning and discussed the process of flipped classroom implementation in language classes. The results were found to be positively correlated to student's motivation as well as the students' academic performance, the model of flipped classroom was found to be more effective in the language classroom.

\section{Step 4: Data Collection-Gathering Information from Secondary Sources and Reviews on FCM}

20 Studies that were screened using Step 2 and Step 3 are tabulated below:

Table 1: Literature Search List

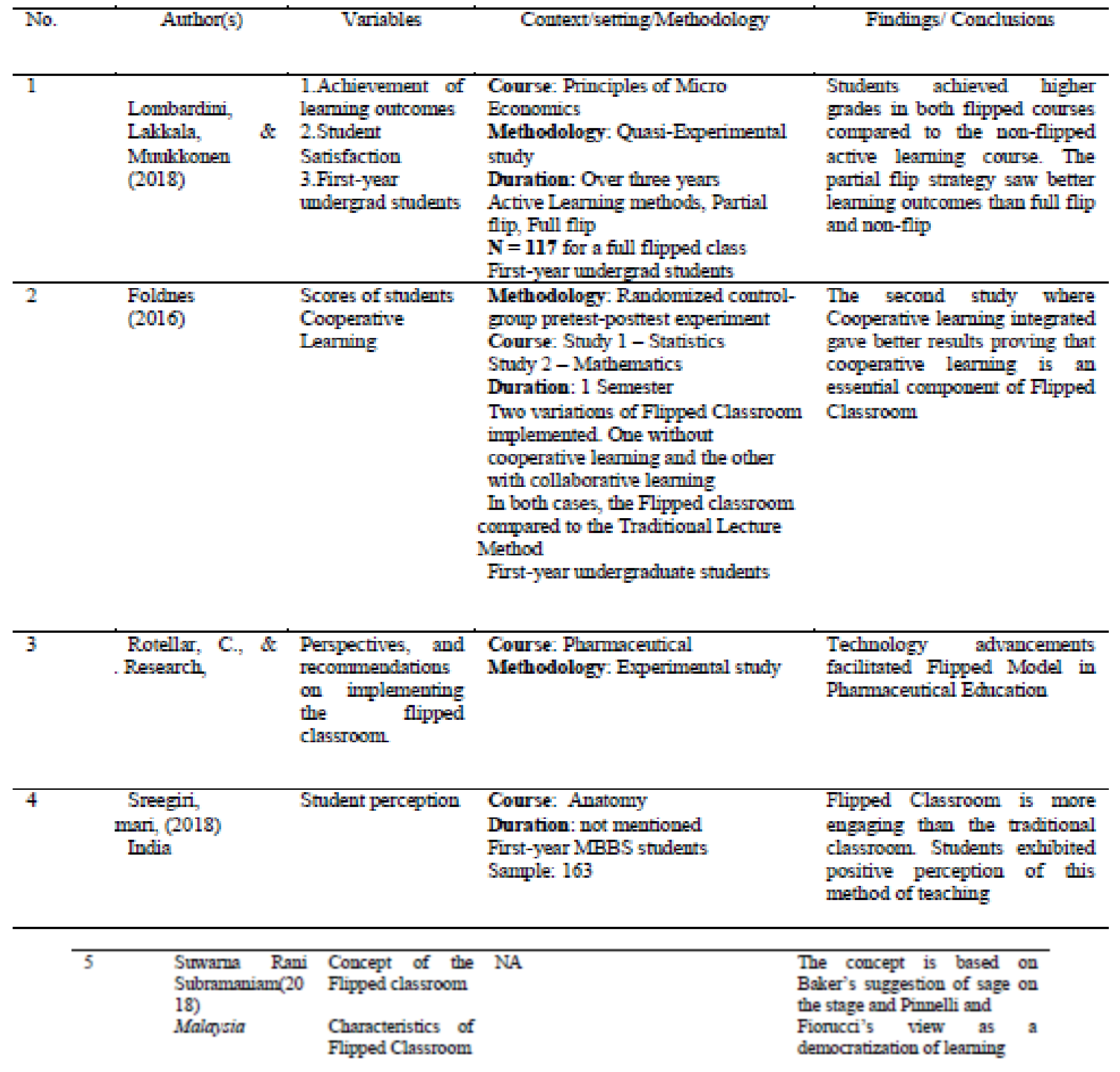

\begin{tabular}{|c|c|c|c|c|}
\hline 6 & $\begin{array}{l}\text { Lo and Hew } \\
(2017) \\
\text { Honghong }\end{array}$ & $\begin{array}{l}\text { Mathematics } \\
\text { achievement }\end{array}$ & $\begin{array}{l}\text { Course: Mathematics } \\
\text { Duration: } 2 \text { to } 4 \text { weeks } \\
\text { One grouq pre-test post-test design } \\
\text { Grade } 12 \text { (Form } 6 \text { ) } \\
13 \text { umderperforning students and } 24 \\
\text { high ability students }\end{array}$ & $\begin{array}{l}\text { Both extremes } \\
\text { underperforming and high } \\
\text { ability students showed } \\
\text { leaming gains using a flipped } \\
\text { classroom }\end{array}$ \\
\hline
\end{tabular}


Flipped Classroom Model - A Response To The Emerging Trends In The Teaching Learning Landscape

\begin{tabular}{|c|c|c|c|c|}
\hline 7 & $\begin{array}{l}\text { Lee and Choi } \\
(2016)\end{array}$ & $\begin{array}{l}\text { modality-related } \\
\text { leamer variables } \\
\text { Self-directedness } \\
\text { Self-regulation } \\
\text { Learning readiness } \\
\text { Academic } \\
\text { performance }\end{array}$ & $\begin{array}{l}\text { Course: Pre-dental curriculum } \\
\text { Duration: } 1 \text { semester } \\
\text { Self-report questionnaire } \\
\text { Undergrachuate students of dentistry }\end{array}$ & $\begin{array}{l}\text { Pre-class leaming helped } \\
\text { achieve the intended learning } \\
\text { gains in FCM } \\
\text { self-directedness but not self- } \\
\text { regulation found to } \\
\text { significantly influence pre- } \\
\text { class leaming performance and } \\
\text { perceived } \\
\text { learning readiness } \\
\text { It contradicts the studies which } \\
\text { claimed self-regulation } \\
\text { changed FCM }\end{array}$ \\
\hline 8 & $\begin{array}{l}\text { Yilmaz } \\
(2017)\end{array}$ & $\begin{array}{l}\text { e-leaming } \\
\text { readiness } \\
\text { Motivation } \\
\text { Satisfaction }\end{array}$ & $\begin{array}{l}\text { Course: Compuring } \\
\text { N= } 236 \\
\text { Duration: } 14 \text { weeks } \\
\text { E-learning Readiness Scale (ELRS), } \\
\text { Satisfaction Scale (SS), and } \\
\text { Motivated Strategies for Leaming } \\
\text { Questionnaire (MSLQ). } 3.2 .1 . \\
\text { Undergrachate students from } \\
\text { departments of science teaching, } \\
\text { social sciences teaching, and Islamic } \\
\text { sciences }\end{array}$ & $\begin{array}{l}\text { Increase in students e-learning } \\
\text { readiness levels increases } \\
\text { student's satisfaction and } \\
\text { motivation in FCM } \\
\text { Students and Teachers } \\
\text { readiness level in e-learning } \\
\text { studied before FCM They } \\
\text { should be provided training on } \\
\text { the elearning skills if needed } \\
\text { before applying FCM }\end{array}$ \\
\hline 9 & $\begin{array}{l}\text { Nguyen, Yu, } \\
\text { Japutra, } \\
\text { (2016) }\end{array}$ & $\begin{array}{l}\text { Students } \\
\text { perception }\end{array}$ & $\begin{array}{l}\text { Course: Advanced Marketing class } \\
\text { Methodology: Action Research } \\
\mathrm{N}=28 \\
\text { Interview protocol with an open- } \\
\text { ended format }\end{array}$ & $\begin{array}{l}\text { Main dimensions of Reverse } \\
\text { teaching are preparation, } \\
\text { Interaction, and Outcome. } \\
\text { There is a crucial link between } \\
\text { these dimensions and the } \\
\text { understanding of reverse } \\
\text { teaching }\end{array}$ \\
\hline
\end{tabular}

\begin{tabular}{|c|c|c|c|c|}
\hline 10 & $\begin{array}{l}\text { Unal \& Unal, } \\
(2017) \\
\text { USAS }\end{array}$ & 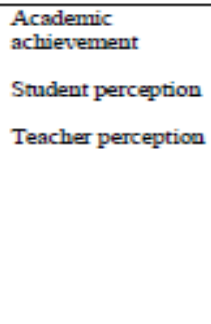 & $\begin{array}{l}\text { Duration: } 5 \text { days } \\
\text { Quasi-experimental method } \\
\text { With comparison groups } \\
\text { Gracuate students who were teachers } \\
\text { in elementary, middle and high } \\
\text { school inmplemented FC for students } \\
\text { ranging from grade } 4 \text { to } 10 \text { in } \\
\text { Mathematics, Science, Social } \\
\text { Studies and Language } \\
16 \text { teachers } \\
623 \text { students }\end{array}$ & $\begin{array}{l}\text { When compared to the } \\
\text { traditional model, students } \\
\text { showed bigher learning gains, } \\
\text { more positive student } \\
\text { perception, amd higher teacher } \\
\text { satisfaction. } \\
\text { The teacher reported increased } \\
\text { opportumities to commumicate } \\
\text { and collaborate with students. } \\
\text { Teachers foumd that the } \\
\text { substantial front end } \\
\text { preparation can be a limitation } \\
\text { and slow down the progress }\end{array}$ \\
\hline 11 & $\begin{array}{l}\text { Hwang, Lai, \& } \\
\text { Wang } \\
\text { (2015) }\end{array}$ & Learning strategies & NA & $\begin{array}{l}\text { Seamless learning which } \\
\text { suggests learning across home, } \\
\text { in-class and in real-world } \\
\text { contexts can achieve by using } \\
\text { the mobile amd wireless } \\
\text { commmication technologies }\end{array}$ \\
\hline 12 & $\begin{array}{l}\text { Fabian \& } \\
\text { Toto, } \\
\text { (2016) }\end{array}$ & $\begin{array}{l}\text { Artitude towards } \\
\text { Mathematics }\end{array}$ & $\begin{array}{l}\text { Duration: whole academic year } \\
\text { Second and third-year high school } \\
\text { students } \\
\mathrm{N}=46 \text { (control group) } \\
45 \text { (experimental group) } \\
\text { Aftitude towards mathematics } \\
\text { Inventor }\end{array}$ & $\begin{array}{l}\text { The gain in student } \\
\text { performance, positive attitude } \\
\text { about Mathematics, positive } \\
\text { perceptions about the } \\
\text { usefulness of the Flipped } \\
\text { classrocm model }\end{array}$ \\
\hline 13 & $\begin{array}{l}\text { Smallhorn, } \\
\text { (2017) }\end{array}$ & $\begin{array}{l}\text { Student } \\
\text { Engagement }\end{array}$ & $\begin{array}{l}\text { Duration: One Semester } \\
\text { Course: Genetics, Evolution, and } \\
\text { Biodiversity }\end{array}$ & $\begin{array}{l}\text { Students were more positive } \\
\text { when the semester progressed } \\
\text { though it varied at the } \\
\text { beginning of the semester. No } \\
\text { steady academic gains. } \\
\text { Suggests that the more than the } \\
\text { theoretical increase the inpact } \\
\text { is on the engagement with } \\
\text { peers and educators that needs } \\
\text { further research using } \\
\text { appropriate tools. }\end{array}$ \\
\hline 14 & $\begin{array}{l}\text { Blau \& } \\
\text { Shamir-Inbal, } \\
\text { (2017) }\end{array}$ & $\begin{array}{l}\text { Role of co-creation } \\
\text { and co-regulation }\end{array}$ & $\begin{array}{l}\text { Duration: } 5 \text { days } \\
\text { College students }\end{array}$ & $\begin{array}{l}\text { Active learning belps improve } \\
\text { results. Teachers felt more } \\
\text { satisfied and declared their } \\
\text { experience as "success." } \\
\text { Provides longer retention, } \\
\text { better commumication, develop } \\
\text { mastery, and personalized } \\
\text { learning }\end{array}$ \\
\hline
\end{tabular}




\begin{tabular}{|c|c|c|c|c|}
\hline 15 & $\begin{array}{l}\text { Harrington, S. } \\
\text { A., Bosch, M. } \\
\text { V., Schoofs, N., } \\
\text { Beel-Bates, C., } \\
\text { \& Anderson, K. } \\
\text { (2015) }\end{array}$ & $\begin{array}{l}\text { Quantitative } \\
\text { outcomes for } \\
\text { mursing students in } \\
\text { a flipped } \\
\text { classroom }\end{array}$ & $\begin{array}{l}\text { Course: Nursing } \\
\text { Methodology: Experimental design } \\
\text { Duration: } 4 \text { Months } \\
\text { Sample: } 82 \text { undergrachate nursing } \\
\text { students }\end{array}$ & $\begin{array}{l}\text { Flipped classrocm leaming was } \\
\text { identified as an effective } \\
\text { strategy for nursing education }\end{array}$ \\
\hline 16 & $\begin{array}{l}\text { Gilboy, M. B, } \\
\text { Heinerichs, S., \& } \\
\text { Pazzaglia, G. } \\
\text { (2015). }\end{array}$ & $\begin{array}{l}\text { Enhancing student } \\
\text { engagement using } \\
\text { the flipped } \\
\text { classroom. }\end{array}$ & $\begin{array}{l}\text { Course: undergraduate nutrition } \\
\text { courses } \\
\text { Methodology: Experimental design } \\
\text { Duration: One Semester } \\
\text { Sample: Two } 400 \text { level } \\
\text { Undergraduate students }\end{array}$ & $\begin{array}{l}\text { Course redesign to incorporate } \\
\text { flipped leaming techniques is a } \\
\text { rewarding experience }\end{array}$ \\
\hline 17 & $\begin{array}{l}\text { Shamma, N., Lan, } \\
\text { C. S., Doherty, } \\
\text { I., \& Harbutt, D. } \\
\text { (2015). }\end{array}$ & $\begin{array}{l}\text { How we flipped } \\
\text { the medical } \\
\text { classroom. }\end{array}$ & $\begin{array}{l}\text { Course: Medicine } \\
\text { Methodology: Experimental design } \\
\text { Sample: } 106 \text { Medical Students }\end{array}$ & $\begin{array}{l}\text { Flipped method of leaning has } \\
\text { positive effects in knowledge } \\
\text { sharing }\end{array}$ \\
\hline 18 & $\begin{array}{l}\text { Geist, M. J, } \\
\text { Larimore, D., } \\
\text { Rawiszer, H., \& } \\
\text { Al Sager, A. W. } \\
\text { (2015). }\end{array}$ & $\begin{array}{l}\text { Flipped versus } \\
\text { traditional } \\
\text { instruction and } \\
\text { achievement in a } \\
\text { baccalaureate } \\
\text { mursing } \\
\text { pharmacology } \\
\text { course. }\end{array}$ & $\begin{array}{l}\text { Course: Phamacology } \\
\text { Methodology: Quasi-experimental } \\
\text { design } \\
\text { Duration: One Semester } \\
\text { Sample: } 40 \text { Undergrachuate students }\end{array}$ & $\begin{array}{l}\text { The flipped model provided } \\
\text { structured learning for better } \\
\text { understanding of concepts. }\end{array}$ \\
\hline 19 & $\begin{array}{l}\text { Hanson, J. } \\
(2016)\end{array}$ & $\begin{array}{l}\text { Surveying the } \\
\text { experiences and } \\
\text { perceptions of } \\
\text { umdergrachate } \\
\text { mursing students of } \\
\text { a flipped } \\
\text { classroom } \\
\text { approach to } \\
\text { increase } \\
\text { umderstanding of } \\
\text { drug science and } \\
\text { its application to } \\
\text { climical practice. }\end{array}$ & $\begin{array}{l}\text { Course: Nursing } \\
\text { Methodology: Descriptive Research } \\
\text { Design } \\
\text { Duration: } 2 \text { Years } \\
\text { Sample: } 187 \text { in First and } 220 \text { in } \\
\text { Second Sannles }\end{array}$ & $\begin{array}{l}\text { Flipped Model has advantages } \\
\text { like deeper thinking, } \\
\text { competence, focus etc. }\end{array}$ \\
\hline 20 & $\begin{array}{l}\text { Burden, M. L, } \\
\text { Carlton, K. H, } \\
\text { Siltberg, L, \& } \\
\text { Pavlechlio, G. } \\
\text { (2015). }\end{array}$ & $\begin{array}{l}\text { Flipping the } \\
\text { classroom: } \\
\text { Strategies for } \\
\text { psychiatric-mental } \\
\text { bealth course. }\end{array}$ & $\begin{array}{l}\text { Course: Nursing } \\
\text { Methodology: Experimental } \\
\text { Research Design } \\
\text { Duration: } 2 \text { Years } \\
\text { Sample: } 359 \text { Students }\end{array}$ & $\begin{array}{l}\text { Flipped Classroom Learning } \\
\text { was effective among students, } \\
\text { therefore faculty plans to } \\
\text { continue the approach showing } \\
\text { a positive outcome. }\end{array}$ \\
\hline
\end{tabular}

\section{Step 5: Interpreting the Evidence}

The findings from the most recent studies shows that different subject areas were dealt with FCM treatment and very interesting variables were studied. Some predominant subject areas are from Engineering, Medicine, Mathematics and Teacher Education.

Different parameters considered in the included studies are tabulated below.

Table 2: Parameters studied in the included studies

\begin{tabular}{lll}
\hline Variables & Outcomes & Studies \\
\hline Learning Outcomes & Positive & $1,2,6,7,10,12$ \\
\hline Learning Outcomes & No change & 13 \\
\hline Engagement & Improved & $4,13,16$ \\
\hline Perception & Positive & $4,10,12,14$ \\
\hline $\begin{array}{l}\text { Concept and } \\
\text { Characteristics }\end{array}$ & NA & 5 \\
\hline Use of Technology & NA & 1 \\
\hline $\begin{array}{l}\text { Deeper Learning, } \\
\text { Knowledge sharing } \\
\text { and Focus }\end{array}$ & Positive & $17,18,19,20$ \\
\hline Real world application & NA & \\
\hline
\end{tabular}

Step 7: Presenting the Report

Transition from TLM to Futuristic Learning Model
In the TLM, the learning content is accessible by the student only through the teacher. A mirroring process is followed in the TLM, where the teachers play the prominent role in distributing knowledge to the student. Student listens, reads and recalls the information shared by the teacher in the class. Therefore, TLM is less interactive and very limiting in its approach.

\section{Traditional Model}

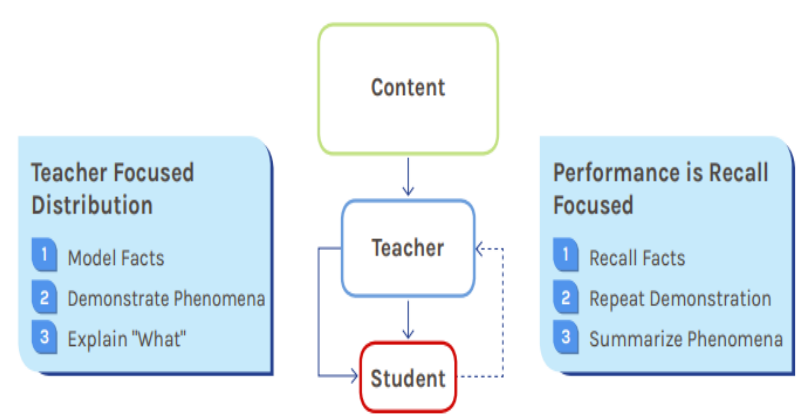

Image 1: Traditional Learning Model (Source: https://www.knowatom.com) 
A futuristic model is comparatively different with its innovative approaches and standards. The role of the teachers changed to a facilitator of learning where they aim to create an inquiring mind among the student community by creating an inquiry atmosphere. Teachers support the students in developing their skills and in rightly engaging their ideas and concepts.

\section{Next Gen Model}

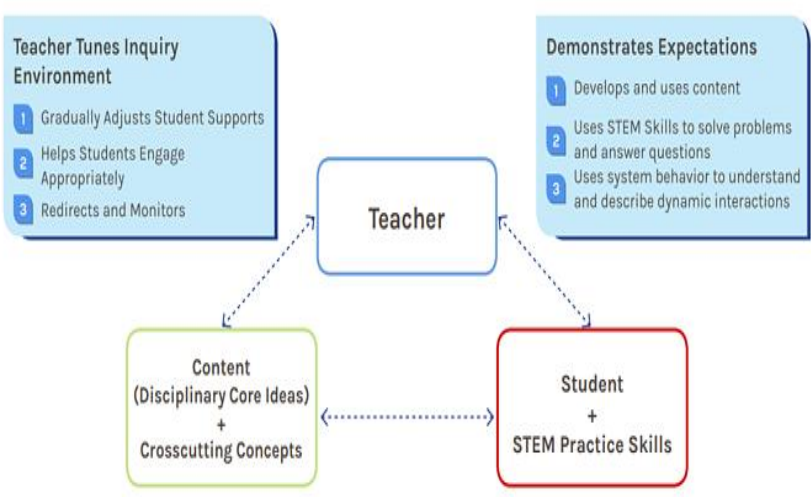

Image: 2 Futuristic Learning Model (Source: https://www.knowatom.com)

The Next Gen Model has clear-cut advantage over the TLM as it is more dynamic. A change from the traditional model is inevitable to gain articulation in curriculum. Students in the new model will be equipped with required capability to deal with unfamiliar questions which need a higher order thinking and upgraded skills.

\section{Flipped Classroom Model}

In a flipped classroom or inverted classroom the learning model is completely reversed. The major activities of learning such as lecturing and home assignments are being flipped or reversed in the new model. Practice assignments which were completed earlier at home is now discussed and worked on during the class hours. Direct instruction or lecturing is provided to students as videos or reading assignments which can be completed at home.

\section{Factors that make FCM a worthwhile activity}

- Students prefer visuals and digital resources

- Time Saving Model

- Video lessons can be viewed with ease by pausing, slowing down or clicking on links

- Prior learning of the topic to be discussed in the class

- Repeated watching or listening of instructional materials is possible

- Equips with upgraded and latest skills.

\section{Key components of FCM}

1. Self-directed Learning: One of the biggest changes that FCM brings in is providing an opportunity to inculcate self-learning habit in learners through the pre-class tasks. The practice in many formal educational institutions is that the control of learning is in the hands of the educators and administrators. In FCM learners take responsibility of their learning by making connections of the new concept with their previous knowledge and constructing meaning to the new content. This is in line with the increasing need to develop lifelong learning habits in the learners.
2. Collaborative Learning: Pre-class tasks allowed learners to gain basic knowledge about the new concept. This freed up classroom time to promote deeper learning by engaging in collaborative in-class activities. Interaction and active participation is possible with group discussion, applications etc. Pre-class videos and discussions will be more cognitive in nature. Collaborative tasks bring in the dimension of metacognition that helps students to be reflective and evaluative about their progress.

3. Integration of Technology: Few researchers consider FCM as a branch out of Blended Learning due it is huge dependency on Technology. To attain the expected outcome from the active learning tasks planned for the in-class activities, learners should come prepared to the class with some basic knowledge and readiness level. Researchers report that E online platforms like Moodle, social networking sites and communication tools like Whats app need to be effectively integrating in the implementation and delivery of FCM.

4. Alternate modes of assessment: The mechanism to assess student learning in FCM must be designed in multiple stages. Pre-class tasks should be assessed using worksheets an writing assignments. Online quizzes provide immediate feedback both to the teacher and the learner. Collaborative activities need to be evaluated not only to check students understanding of the concepts but also on their ability to work in groups and presentation skills. The level of student understanding can be evaluated from the rate of video participations and the tough concepts which need more detailed explanations, and can be done in direct interaction.

The Challenges in adopting FCM

The success of the Flipped Classroom Model depends on

1. Internet Speed and Availability: The speed of the Internet connection determines the speed of data download and upload. Speed gets affected by hardware, software, number of users etc. It is suggested that the teachers have thought of alternate solutions like sharing the digital resources in flash drives or through other online mediums where the resources can be downloaded.

2. Different instructors explaining the concept in different ways: The videos and resources found on the internet may not suit the learners because of alternate approaches or language or the difficulty level of the content dealt in. It is suggested that the teachers get trained to produce some digital resources in such situations.

3. Digital Absenteeism: It is not guaranteed that students will watch the videos or other digital resources that are assigned to them as self-study material. It is suggested that attendance or grades are linked with the pre-class activities. Care should also be taken to ensure that the mere access of resources should not be awarded grades but the pre-test tasks should include some work to assess the quality of student.

This study aims to analyse the benefits of implementing flipped classroom based on the chosen 20 articles that report on flipped learning classroom initiatives between the years 2016-2018. It was observed that research into the flipped classroom engaged different 
areas of studies, methodologies and technology tools or online platforms.

The flipped classroom motivated students to study at their own pace and made classroom time available for interactive learning activities. It also benefitted students academically and motivationally.

\section{Practical Implications: The impacts of applying FCM on student's learning}

FCM helped teachers as well as students in managing time effectively. Instead of giving instructional lectures in the class, educators can utilize the classroom time in the best manner. Learners can learn the different concepts at their own pace and engage in discussions with the educators during the direct interaction. Information can be accessed repeatedly in the flipped model, so the level of understanding can be more. Opportunities of giving feedback to the learners increases in FCM. There is scope for the educators to personalize the content according to the capability of different learners.

FUTURE SCOPE OF THE STUDY: From the responses of the teachers and students who have adopted FCM, it is clear that Flipped learning is a necessary learning strategy to achieve relevant and meaningful educational outcomes. Rigorous experimental studies should be carried out in different geographical locations to understand the impact of FCM in the global context. More studies should be carried out to examine the suitability of Flipped Classroom Model in K-12 segment.

FCM has emerged over the last two decades. There is more work to be done to further our understanding of FCM. A particular challenge will be to develop a framework for the instructional design for FCM. Future studies should not only focus on videos and other digital resources for self-learning by students but should also give more importance to structure and design of in-class activities that will deepen the students learning. The flipped classroom model should be practiced correctly and thoughtfully to develop students higher cognitive domains.

Some future research directions would be to understand the influence of FCM in developing lifelong learners who possess the capacity of self-initiated educational growth. The current emphasis on FCM makes it appropriate to understand the psychological dimensions of FCM.

\section{CONCLUSION:}

Educators and learners need a changed mindset to accept a new strategy like Flipped Classroom Model. Active learning methods help students to develop creativity and higher order thinking skills. It gives the students an engaging experience and an efficient way of understanding different topics. Students develop self-efficacy in independent learning. Students prefer interactive learning than in-person lecturing. When compared to traditional instructional methodologies, student learning is improved with flipped classroom models. The flipped model provides opportunity for educational institutions to provide more relevant and meaningful learning to millennial students.

\section{REFERENCES:}

1. Arina, Evseeva. Anton, Solozhenko. Use of Flipped Classroom Technology in Language Learning, Procedia - Social and Behavioral Sciences, (2015); 206 (17): 205-209

2. Baker, J. W. (2000). The Classroom Flip : Becoming the Guide by the Side. CCCU Annual Technology Conference, 1-28.

3. Bishop, J., \& Verleger, M. (2013). The Flipped Classroom: A Survey of the Research. 120th ASEE Annual Conference \& Exposition, 161-163. https://doi.org/10.1109/FIE.2013.6684807

4. Blau, I., \& Shamir-Inbal, T. (2017). Re-designed flipped learning model in an academic course: The role of co-creation and co-regulation. In Computers and Education (Vol. 115). https://doi.org/10.1016/j.compedu.2017.07.014

5. Burden, M. L., Carlton, K. H., Siktberg, L., \& Pavlechko, G. (2015). Flipping the classroom: Strategies for psychiatric-mental health course Nurse educator, 40(5), 233-236.

6. Carlisle, M. C. (2010). Using YouTube to enhance student class preparation in an introductory Java course. (January 2010), 470. https://doi.org/10.1145/1734263.1734419

7. Cooper, Harris M \& Cooper, H. M. (2010). Synthesizing research (2010) Research synthesis and meta-analysis : a step-by-step approach (Fourth edition). SAGE Publications, Los Angeles.

8. Corno, L., \& Mandinach, E. B. (1983). The Role Of Cognitive Engagement in Classroom Learning and Motivation. Educational Psychologist, $18(2)$, https://doi.org/10.1080/00461528309529266

9. Fabian, K., \& Toto, C. (2016). Flipped Classroom Model: Effects on Performance, Attitudes and Perceptions in High School Algebra 9891(October 2017). https://doi.org/10.1007/978-3-319-45153-4

10. Foldnes, N. (2016). The flipped classroom and cooperative learning: Evidence from a randomised experiment. Active Learning in Higher Education, 17(1), 39-49. https://doi.org/10.1177/1469787415616726

11. Geist, M. J., Larimore, D., Rawiszer, H., \& Al Sager, A. W. (2015) Flipped versus traditional instruction and achievement in a baccalaureate nursing pharmacology course. Nursing Education Perspectives, 36(2), 114-115.

12. Gilboy, M. B., Heinerichs, S., \& Pazzaglia, G. (2015). Enhancing student engagement using the flipped classroom. Journal of nutrition education and behavior, 47(1), 109-114

13. Hanson, J. (2016). Surveying the experiences and perceptions of undergraduate nursing students of a flipped classroom approach to increase understanding of drug science and its application to clinical practice. Nurse education in practice, 16(1), 79-85.

14. Harrington, S. A., Bosch, M. V., Schoofs, N., Beel-Bates, C., \& Anderson, K. (2015). Quantitative outcomes for nursing students in a flipped classroom. Nursing Education Perspectives, 36(3), 179-181.

15. Hwang, G.-J., Lai, C.-L., \& Wang, S.-Y. (2015). Seamless flipped learning: a mobile technology-enhanced flipped classroom with effective learning strategies. Journal of Computers in Education, 2(4), 449-473. https://doi.org/10.1007/s40692-015-0043-0

16. Jin Su Jeong, D. G.-G. (2018). The Study of Flipped-Classroom for Pre-Service Science Teachers. Education Sciences, 1-11. https://doi.org/10.3390/educsci8040163

17. Kevin, R, Clark. The Effects of the Flipped Model of Instruction on Student Engagement and Performance in the Secondary Mathematics Classroom, Journal of Educators Online, (2015); 12(1): 91-115

18. King, A. (1993). From Sage on the Stage to Guide on the Side. College Teaching, 41(1), 30-35. https://doi.org/https://doi.org/10.1080/87567555.1993.9926781

19. Lee, J., \& Choi, H. (2019). Rethinking the flipped learning pre-class: Its influence on the success of flipped learning and related factors. British Journal of Educational Technology, 50(2), 934-945. https://doi.org/10.1111/bjet.12618

20. Lo, C. K., \& Hew, K. F. (2017). Using "First Principles of Instruction" to Design Mathematics Flipped Classroom for Underperforming Students. International Journal of Learning and Teaching, (January). https://doi.org/10.18178/ijlt.3.2.82-89

21. Lombardini, C., Lakkala, M., \& Muukkonen, H. (2018). The impact of the flipped classroom in principles of microeconomics course: evidence from a quasi-experiment with two flipped classroom designs. International Review of Economics Education, 29(January), 14-28. https://doi.org/10.1016/j.iree.2018.01.003

22. Maureen J. Lage, G. J. P. and M. T., Lage, M. J., Platt, G. J., \& Treglia, M. (2000). Inverting the Classroom: A Gateway to Creating an Inclusive Learning Environment. The Journal of Economic Education, 31.

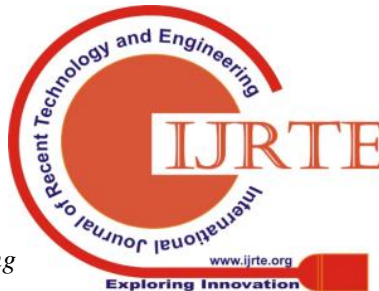


https://doi.org/10.1080/00220480009596759

23. Nguyen, B., Yu, X., Japutra, A., \& Chen, C. H. S. (2016). Reverse teaching: Exploring student perceptions of "flip teaching." Active Learning in Higher Education, 17(1), 51-61. https://doi.org/10.1177/1469787415616727

24. O'Flaherty, J., \& Phillips, C. (2015). The use of flipped classrooms in higher education: A scoping review. Internet and Higher Education, 25 85-95. https://doi.org/10.1016/j.iheduc.2015.02.002

25. Pinnelli, S., \& Fiorucci, A. (2015). University and flipped learning ti $\{c ̧\}$ project: Framework and design. Proceedings of the 12th International Conference on Cognition and Exploratory Learning in the Digital Age, CELDA 2015, (Celda), 217-224. Retrieved from https://www.scopus.com/inward/record.uri?eid=2-s2.0-84961770633\% 7B\&\%7DpartnerID=40\%7B \&\%7Dmd5=9eb9763dba445028478cc0a2 c52a7072

26. Rotellar, C., \& Cain, J. (2016). Research, perspectives, and recommendations on implementing the flipped classroom. American journal of pharmaceutical education, 80(2), 34

27. Sharma, N., Lau, C. S., Doherty, I., \& Harbutt, D. (2015). How we flipped the medical classroom. Medical teacher, 37(4), 327-330.

28. Smallhorn, M. (2017). The flipped classroom: A learning model to increase student engagement not academic achievement. Student Success, 8(2), 43. https://doi.org/10.5204/ssj.v8i2.381

29. Sreegiri, S., Madhavi, B. D., \& Kumari, L. (2018). Student's Perception of Flipped Classroom Teaching Method in Andhra Medical College , Visakhapatnam. 17(2), 6-9. https://doi.org/10.9790/0853-1702010609

30. Stacy, M, P, Schmidt. David, L, Ralph. The FlippedClassroom: A Twist On Teaching, Contemporary Issues in Education Research, (2016); 9(1): $1-6$

31. Suwarna Rani Subramaniam, B. M. (2018). Concept and Characteristics of Flipped Classroom. International Journal of Emerging Trends in Science and Technology, (October 2016). https://doi.org/10.18535/ijetst/v3i10.01

32. Unal, Z., \& Unal, A. (2017). Comparison of Student Performance, Student Perception, and Teacher Satisfaction with Traditional versus Flipped Classroom Models. International Journal of Instruction, 10(4), 145-164. https://doi.org/10.12973/iji.2017.1049a

33. Yilmaz, R. (2017). Exploring the Role of E-Learning Readiness on Student Satisfaction and Motivation in the Flipped Classroom. Computers in Human Behavior, 70(January 2017), 251-260. https://doi.org/10.1016/j.chb.2016.12.085 